\title{
RUSSIAN GENIUS LOMONOSOV AS A PIONEER AND POPULARIZER IN SCIENCE
}

\author{
M. MAEVSKAYA ${ }^{1, *}$, L. GROMOVA ${ }^{2}$ \\ ${ }^{1,2}$ Sant Peterburg State University \\ mari-maevskaya@yandex.ru
}

Received 14/08/2017 - Accepted 19/11/2018

DOI: $10.15628 /$ holos.2018.7882

\section{ABSTRACT}

The article analyzes the promotional activity of outstanding Russian encyclopedist Michail Lomonosov who founded the fundamentals of science in Russia and tried to make scientific knowledge available for the wide range of readers in the XVIII century. Also, different forms of dissemination of scientific knowledge that Lomonosov used in the academic and educational activities were examined in the article.

KEYWORDS: Michail Lomonosov, academy, science, discoveries, scientific popularization

\section{LOMONOSOV - GÊNIO RUSSO E PIONEIRO DA POPULARIZAÇÃO DA CIÊNCIA}

\section{RESUMO}

$\mathrm{O}$ artigo analisa a atividade promocional do famoso cientista-enciclopedista russo, Michail Lomonosov, que criou os fundamentos da ciência na Rússia e disponibilizou o conhecimento científico para a ampla

gama de leitores do século XVIII. Além disso, apresenta diferentes formas de disseminação do conhecimento científico que Lomonosov utilizou nas atividades acadêmicas e educacionais serão examinadas no artigo.

KEYWORDS: Michail Lomonosov, acadêmia, ciência, descobertas, divulgação científica. 


\section{INTRODUCTION}

\subsection{The relevance of studying the Lomonosov's experience}

The syncretic character was very typical for the development of Russian science from its early stages of evolution, that is considering different kinds of knowledge as a single knowledge of the world and mankind. Interdisciplinarity has opened new discoveries and perspective directions. Russian science has never been separated from public life and Russian scientists who followed their mission used to various kinds of publicity. Even methodological schools asserted themselves through publicistic discourse in Russia. Therefore, the alliance of science was in a demand in the national tradition of enlightenment. The idea of popularization of scientific knowledge is reviving in modern Russia on the basis of the accumulated historical experience. The experience of Mikhail Vasilyevich Lomonosov (1711-1765), the scientist and the popularizer of science, who clearly demonstrated multidisciplinary approach to the cognition and dissemination of scientific knowledge in society in his work, still remains very relevant.

This article sets the goal to reconstruct some relevant for today's life aspects of Lomonosov scientific biography.

\subsection{Materials and methods}

The empirical materials of this study are the original Michail Lomonosov's articles which were published in Russian magazines in XVIII century as well as the content of other researches from old and new times. These texts were studied using methods of analysis of the historic materials. In addition, we used a comparative method and contextual analysis.

Lomonosov's scale of activities was greatly huge; in the world science, there are not many examples that could be compared with him. He was called the Russian Leonardo DaVinci. The pioneer in many areas of Russian science, the encyclopedist, Lomonosov succeeded in the theory and practice of natural and humanities science. The influence of Lomonosov on Russian science and culture is characterized by S.I. Vavilov, the well-known academician and popularizer of science: "The influence of his genius and his works are immeasurable. Lomonosov influenced a lot on our language, our grammar, poetry and literature. Our Academy of Sciences received its real being and meaning only through Lomonosov works. If you look carefully, it becomes clear that the cornerstones of the successes of our science were laid down in the past by Lomonosov" [Vavilov, 1961, p. 32].

Lomonosov became a pioneer in the studies of Russian history, physics, mathematics and astronomy and was elected as a member of the Swedish and Bologna Academies. This number of merits in sciences could be supplemented by chemistry, metallurgy, geography, geology and also physical chemistry and economic geography that were founded by him. He was the creator of Russian scientific terminology, without which the development of science is unthinkable. He stood at the origins of university education in Russia: he was the rector of Saint Petersburg University that was founded by the Academy of Sciences in 1724 [Kulyabko, 1962, p. 24]. Also he was the initiator of Moscow University opening in 1755 [Minaeva, 2011, p. 56]. He created an education system in gymnasiums at these universities.

The biography of $\mathrm{M}$. Lomonosov that had a lot of secrets and legends has given plots for numerous novels. He was born in Denisovka village of Arkhangelsk province in the north of Russia in a family of fisherman. All authors who write about the scientist's childhood mention the 
influence of northern nature on his life and work. At the age of 10 he began studying literacy with the deacon of the local church. He studied arithmetics by himself. Religious books were the only books available for Lomonosov at that period. But his aspiration to continue educating was very strong, so he left his family and usual environment, and went to the capital of Russia on foot. Lomonosov studied diligently and he showed a great success, especially in Latin and Greek languages. A few months later he was already writing poems in Latin. After one year of studying he completed a three-year course, and then he studied for about four and a half years at the Slavic-Greek-Latin Academy. Among the best students he was sent to St Petersburg University at the Academy of Sciences in the end of 1736; a few months later he was sent to Germany, to Marburg University to study mining. His spectrum of interest was unusually wide abroad. He returned to Russia in 1741 and was invited at the staff to the Academy of Sciences, firstly as a junior researcher, and later as a professor (academician) in 1745 . He became the first Russian professor of St Petersburg Academy of Sciences that was initially formed mostly of German academics at those times. He was the first to read public lectures on physics in Russian language.

\section{PROBLEM QUESTION DECISONS}

\subsection{Sources of scientific biography}

There are few sources of Lomonosov's scientific biography: these are the documents of the Academy of Sciences and biographies written on its basis [Bilyarskiy, 1861, p. 5] as well as the memories of Lomonosov written down by the academician Jakob Shtelin under the title "Features and anecdotes for the biography of Lomonosov, taken from his own words by Shtelin". Note that the word "anecdote" in the XVIII century meant a story including stories about personal life, relationships with other people and everyday details. In the middle of the XIX century Shtelin's "Anecdotes" about Lomonosov were published in the "Moskvityanin" magazine [Menshutkin, 1911, p. 75].

The important sources are also the publications in the newspapers "Sankt Peterburgskie Vedomosti" and "Moskovskye Vedomosti" that started to be published in 1756 after the foundation of Moscow University. According to O.D. Minayeva's estimations, these two newspapers (because others simply did not exist in Russia at that time) three dozens of times told about Lomonosov during his life [Minaeva, 2011, p.5]. However, most of these publications are only announcements about his books sale and academic activity, while only seven of them contained information about Lomonsov's life. A big interest in his personality was growing from century to century. The celebration of the memorable dates (in 1865 and 1911) aroused a special attention. The review of critical and literary works written about Lomonosov over a hundred years are presented in the book of T.F. Pirozhkova and shows how great the interest in his personality was after his death, when the comprehension of scale of his activities has really begun.

There are nearly 110 publications about Lomonosov in the first half of the XIX century. Journalists were interested in the biography of the scientist, in the memoires of his contemporaries and the interest has noticeably deepened in the second half of the XIX century. There are about 400 publications [Minaeva, 2011, p. 6] in which one could see Lomonosov as a poet. He laid the foundations of modern Russian language. Also, as an artist, a historian, a promoter of national education and a developer of independent Russian science. At the beginning of the XX century, the scientific community realized his achievements in chemistry, 
physics, metallurgy, geology, and other branches of sciences. The publications emphasized how far he had surpassed the science of that time.

In the XIX and at the beginning of the XX century the leading periodicals wrote about Lomonosov, such as the "Vestnik Evropy", "Otechestvennye Zapiski", "Moskvityanin", "Biblioteka dia Chteniya", "Russkie Razgovori", "Russkaya Starina" magazines; the "Sankt Peterburgskie Vedomosti", "Moskovskie Vedomosti", "Literaturnaya Gazeta", "Novoye Vremya", "Russkie Vedomosti" newspapers along with many other. The scientific magazines (for example, "Zapiski Akademii Nauk", - "News of the Academy of Sciences") wrote constantly about Lomonosov's works and his personality. It is quite hard now to add new facts about Lomonosov and we are going to consider his biography in terms of popularizing of science, disseminating scientific knowledge in Russian society and promoting Russian discoveries overseas.

All Lomonosov achievements are connected with the Academy of Sciences. In the XVIII century, the activity was divided between four main directions: research, technical application field, cultural-educational and pedagogical fields. The main focus was on solving natural science issues. The Academy retained the principles of Peter's the Great (Russian Tsar) approach to science and enlightenment. Peter the Great ordered the Academy not only to perform research work but also to popularize the science, including systematic reading of public lectures by academicians, publishing textbooks, popular science books and magazines. He took part personally in editing popular publications, articles and brochures, considering enlightenment as the duty of each educated person; he demanded accuracy, clarity, and accessibility of the materials presentation [Gromova, Maevskaya, 2012, p. 2]. Scientific researches of St Petersburg academicians were formed as articles in the multivolume edition of "Comments" and in other publications entered the international scientific information system. The Academy of Sciences set the foundation for the development of popular science journalism in Russia. Whole series of print editions, different in content, periodicity and a readership were presented in the XVIII century:

- scientific publications for specialized groups of scientists - "Commentarii Academiae Scientiarum Petropolitanae" (1728-1751), "Kratkoe opisanie Kommentariev Academii Nayk" (1728-1751), "Novie Commentarii Academiae Scientiarum Petropolitanae" (17501776), "Novie Commentarii Petersburgskoi Academii Nayk"(1750-1776);

- newspapers as academic publications, but designed for a wider range of readers - "St Petersburgische Zeitung" (1727-1774) and "Sankt Peterburgskie Vedomosti" (1728-1875);

- popular science journals for a mass versatile readership - "Mesyachnie Istoricheskie, Genealogicheskie i Geographicheskie Primechaniya v Vedomosti" as a supplement to the "Sankt Peterburgskie Vedomosti" (1728-1742), "Ezhemesyachnie Sochineniya k Polze I Uveseleniu slyzhashie" (1755-1764).

These publications were shipped to different scientific communities, largest libraries of foreign countries, editorial board of number of journals, and directly to scholars - foreign members of the Academy, its foreign book sellers and commissioners. More than a dozen of magazines published in Western European cities printed extensive abstracts of scientific works of St Petersburg academics or their reviews in the XVIII century. The spread of natural knowledge acquired a larger readership and "went through" the books, calendars and magazines.

Concerning the initial stage of the development of scientific popularization in Russia, we should mention the enormous contribution to the development of science and the spreading the scientific knowledge made by Mikhail Lomonosov. The period of academic book printing in 1741- 
1765 was rightly called the Lomonosov period in the history of the Academy of Sciences [Tyulichev, 1988, p. 9].

\subsection{Printed and oral forms of science popularization}

Nearly 80 different scientific works, popular scientific works and literary works in the form of separate books and pamphlets were published by St Petersburg Academy of Sciences during Lomonosov's lifetime. Along with them, about 50 different works of the scientist during his lifetime were printed in periodicals and in collections of the Academy of Sciences [Tyulichev 1988, p. 213].

An important role in the development and popularization of science belonged to Lomonosov's works which were published as articles (they were more often called dissertations at that time) in the main scientific journal of the Academy of Sciences - "Commentaries" and its additional version - "New Commentaries". We are talking on seven articles of Lomonosov in Latin. In 1742-1744, Lomonosov started actively to develop a corpuscular theory about the structure of matter, setting the foundations of modern atomic theory. He created few works: "The experience of the theory of insensitive particles and generally about the causes of particular qualities", "About insensitive physical particles of the bodies", etc. In December 1744, Lomonosov introduced the Academic Assembly with his theses: "About the free movement of air", "About effect of solvents on the dissolved bodies". Lomonosov's public reading of his theses lasted several days. In January 1945, he presented his study "Considering the nature of cold and warmth". In June 1745, the study "On lightness of metals" was published. In 1746, he was the first to start reading public lectures on physics in Russian, "Sankt Peterburgskie Vedomosti" wrote on this on June 24, 1746. His lectures were attended by a huge number of people, including court gentlemen and high-society ladies.

It was the initiative of Lomonosov to open a public lecture hall at the Academy of Sciences in 1746 where lectures in physics, accompanied with a demonstration of experiments, were held in Russian language. Reviving the traditions of ancient authors, he sought to give a popular presentation of scientific and technical problems in artistic and poetic forms. Lomonosov speeches, which he held in a public meeting of the Academy of Sciences ("About the benefits of chemistry", "About the phenomena of air, happening from the electrical force", "About the birth of metals from earth shaking") were a new stage in spreading of scientific knowledge and in the propagation of Russian science. In his famous "Letter on the benefits of glass", Lomonosov described the creation and properties of glass, its usage in beads, glasses, telescopes, and barometers; he touched the other scientific issues, expounded the doctrine of Copernicus, and told on astronomy in a poetic form.

Lomonosov experimented a lot with the production of glass. His success in mosaic art was presented in "Florentine scientific sheets" in March 1764. The translation of the article was published in the St Petersburg magazine where also Lomonosov's dissertation about light and colors was mentioned ["Ezhemesyachnie sochineniya i izvestiya ob ychenih delah", 1764, p. 465]. In his "Letter on the benefits of glass" and other poetic works ("Morning reflection on the Majesty of God", "Evening reflection on the Majesty of God") Lomonosov proclaimed a genuine synthesis of science and arts [Gromova, Balashova, 2017, p. 82].

Lomonosov wrote a thesis "About the birth and nature of nitrate" (1749), where he called for scientists to "connect physical truths with chemical truths." He laid the foundations of modern physical chemistry. Developing the problems of this science, Lomonosov read a course 
on physical chemistry for the first time in the world practice. He loved chemistry so much and even devoted poetry to it.

Each discovery and a comprehension of new theories, besides oral presentations to a scientific audience, became well-known to general public through publications in newspapers. Thus, in 1756, at the meeting in the Academy of Sciences the scientist delivered a report entitled "Word on the origin of light", where he associated light radiation with the movement of matter. He was a supporter of the wave theory of light developed by H. Huygens, and he criticized I. Newton's theory for many inconsistencies. The speech was published in "Sankt Peterburgskie Vedomosti" newspaper and it was reported about offering readers to buy the speech in an academic bookshop. Thus, even at the dawn of Russian science development, Lomonosov was concerned about the dissemination of scientific information both in the professional environment and among the mass reading audience.

A significant part of Lomonosov's working as a scientist and enlightener was the program of publishing activities at the Academy of Sciences and at the Moscow University. It is known that the design of Moscow University project, created in 1755 on the initiative of Lomonosov, provided a printing house (the only civilian printing house in Moscow th that time) and the first public library in Moscow. It became a powerful channel for the accumulation and dissemination of scientific knowledge throughout Russia. In February 1757, the printing house of Moscow University began printing a two-volume collection of works by Lomonosov. This edition contained poems and scientific and journalistic articles. Messages about selling out the essays of a scientist were published in "Moskovskie Vedomosti" newspaper which has appeared at Moscow University since April 26, 1756. It was the first and only newspaper in the XVIII century in Moscow. "Moskovskie Vedomosti" was created by the University teachers and students and printed at the University publishing house. The newspaper regularly published reports on the activities of the Academy of Sciences in St Petersburg. The collection of Lomonosov's works published at the Moscow University printing house was also sold in the academic bookshop in St Petersburg. It was reported by the "St Petersburg Gazette" in September issues of 1758.

The main goal of all organizational, scientific, literary and pedagogical activities of Lomonosov was to spread an education in Russia. In the country where education was legally enshrined in the privilege of the nobility, Lomonosov sought to spread education in all sectors of society. The main tool for the development of education he considered the book. He had a particularly great influence on the wide spreading of academic books in the last 8 years of his life. He was one of the leaders of the Academy of Sciences and could actively influence on academic book printing.

His books about the history of Russia were very popular among his contemporaries. In 1759, he finished his "Brief Russian chronicle with genealogy". This was a short history of Russia accessible to many readers. "Brief Russian chronicle" was repeatedly published in foreign languages - German, English and French. It is known that it was prepared by Lomonosov incidentally, while working on the study of Russian early history. The result was the fundamental "Ancient Russian history" translated into German, English and French. The publication of the "Ancient Russian history" played a very important role in the research of Russian history and gave an access to it for many readers.

"A Brief guide to eloquence", prepared by M.V. Lomonosov and published in 1848, became the first Russian textbook on the theory of Russian prose and oratorical art. It was also unexpected and surprising for the XVIII century realities that Lomonosov's "Rhetoric" would become so extremely popular. The editions were sold out very quickly. Lomonosov's first Russian language grammar book, where we could find the foundations of Russian linguistics, became an 
outstanding event in the history of Russian culture in 1754-1755. Through the second half of the XVIII century and even at the beginning of the XIX century, the "Russian grammar" by Lomonosov was an irreplaceable textbook. It helped Russian people to learn reading and writing. In 1757, it was translated into German [Poleznoe Uveselenie. 1760. Janiary].

Regarding to Lomonosov's interest in publication of popular science and educational literature, we should mention his role in preparation and printing other textbooks, namely foreign languages and dictionaries. For example, on November 17, 1757, he suggested the Chancellery of the Academy of Sciences to instruct K.F. Moderakh, the inspector of the Academic Gymnasium, to make the German-Russian dictionary, which was so necessary for schoolboys. Lomonosov's participation and initiatives in publishing Latin grammar books is very little-studied but so important for the science. Latin language had a very important information role in science at that time. Thus, Lomonosov who knew Latin language brilliantly insisted on its studying by the students of the Academic Gymnasium [Tyulichev, 1988, p. 239].

\subsection{Participation in journalism}

Journalism for Lomonosov was one of the main channels of education and popularization of science. He initiated the creation of new periodicals, took part in the organization and issues of periodicals, and worked as the author.

In 1741-1742, Lomonosov also worked as an author for "Primechaniya" (full: "Istoricheskie, Genealogicheskie I Geographiceskie Primechaniya"), a supplement to the newspaper "Sankt Peterburgskie Vedomosti", under the supervision of the Academy of Sciences. Lomonosov, waiting to be taken at the staff of the Academy after finishing his education in Germany, worked in the newspaper as an author and as an interpreter, as "freelance", receiving 10-15 rubles "for food". His debut as an interpreter in "Primechaniya" occurred with an article "On preservation of health", written by academician Kraft and translated from the German language. In total, there were 10 Lomonosov's translations in 1741 and 8 in 1742. In May 1748 the Chancellery of the Academy asked Lomonosov, who was already a professor, to work for the newspaper "Sankt Peterburgskie Vedomosti", where he actually worked as an editor (Zapadov, 1961, p. 21].

Despite being extremely busy he took this additional job with great responsibility. The number of scientific reports has increased, the language of the newspaper has become clearer and accessible for the readers. However, excessive regulations and nagging of the Chancellery of the Academy, which sometimes created conflict situations, forced Lomonosov to leave this position. In 1751, he filed a petition for "dismissal from editorial duties", motivating it with great over-employment. Lomonosov's participation in Russian journalism still continued and he became the initiator of "Ezhemesyachnie Sochineniya, k Polze I Uveseleniu Sluzhachie" ("Monthly Works for Benefits and Amusement") in 1755. This magazine became the first popular scientific journal in Russia (the magazine existed until 1764).

In the late 50 s and early 60s, Lomonosov made a few suggestions to the Academic Chancellery to establish a number of new periodicals for a mass audience but these projects remained unfinished. For example, on May 4, 1758, Lomonosov submitted to the Chancellery a document where he outlined his draft of the weekly "Sankt Peterburgskie Vedomosti o Delax Uchenih Ludei" (it was the newspaper for educated people on the men of sgience) in Russian and also in German and French languages. According to his plan, abstracts and annotations of new national and foreign books and reviews on them, reports on new works of Russian scientists before they are published in the press, and also news about scientific achievements at the 
foreign universities would have been published in a popular form in this weekly magazine. Another project presented on June 15, 1759, also remained unrealized. It concerned the establishment of the "Russian Gazette" that was going to inform about the economy and trade, and would have contributed to the development of Russia's economic life. The project was sent to the Senate for consideration but the decision of the Senate on this document is still not known [Chronicle of life and creativity of M.V. Lomonosov, 1961, p. 77].

By the 1750s, academic journalism in Russia had more than 20 years of experience, which needed to be comprehended, summarized, and evaluated. The article by Lomonosov, called "Discourses on the duties of journalists" put questions about the tasks of the journalism and journalist, the shortcomings of modern journalism and the ethical image of the journalist. The article addressed the problems of scientific journalism. However, Lomonosov considered the problem broadly, philosophically, in terms of possibilities for free development of scientific judgments. The ideas expressed in the article can be attributed not only to scientific journalism, but to journalism in general. Many of them are relevant even today.

The specific situation in European scientific journalism urged him to write this article. It was related to Theory of Heat created by Lomonosov in 1744 . His theory was criticized by one of the journalists from Leipzig in 1752 and two years later the "Hamburg Correspondent" published an article about the dissertation of a certain Arnold, who also refuted Lomonosov's theory. This situation was quite typical for the scientific journalism at those years when inaccuracies, misunderstandings, erroneous or superficial judgments, misrepresentation were not uncommon in both researches and scientific publications. This case prompted Lomonosov to write an article about ethical rules of science journalism. The article "Discourses on the duties of journalists" was written by M.V. Lomonosov in 1754 in Latin and published in 1755 by the French magazine "Nouvelle Bibliothèire de lérie 'Allemagne, de la Suisse et des Pays du Nord', in Amsterdam in French language. The original copy of the article was unfortunately lost. The article was translated into Russian more than a hundred years later, in 1865.

Relating to the rules to be learned by a journalist he says: "Whoever undertakes to inform the public about the content of the new essays must first weigh up his strength in order to be able to grasp the new and essential in the essays which sometimes belong to the most ingenious people ... A journalist should not rush to reprove hypotheses. They are permissible in philosophical subjects and this is even the only way that the greatest people managed to discover the most important truth..." Lomonosov writes that a journalist must first get familiarize with the author's thoughts, analyze all his evidence and finally "he should never have a high opinion of his superiority, his authority and the dignity of his judgments..." He formulates the famous seven rules that have not lost their significance even today: do not steal other people's discoveries, prove your hypotheses treat with respect, without prejudice to the opinions of others, etc. In these arguments Lomonosov focused on a whole complex of the most important ethical and professional issues relevant for today's journalism. It is no coincidence that historians of Russian journalism consider "Discourses on the duties of journalists" as the first ethical code of journalists [Gromova, Maevskaya, 2012, p. 37]. Drawing the image of the ideal journalist, Lomonosov painted the image of the ideal popularizer, who perfectly knows the subject and selects only the new and essential matter from all the information. For the popularization of science, Lomonosov set the task "to divert from people who were not enlightened by any teaching, any unsubstantiated doubts and fears, which sometimes are the cause of disturbing the general peace" [Lomonosov, 1950, p. 353]. 


\section{CONCLUSION}

During the period of 23 years of working at the Academy, Lomonosov has managed to create the foundation for multiple fields of Russian science and initiated its popularization in various forms. As an encyclopedist he was engaged in the popularization of science in all directions of his versatile activity. His discoveries were reflected in scientific articles (theses) and poetical works, in fundamental researches and practical experiments, in public lectures and also in the development of university education, in scientific discussions and in letters. During his journalism practice Lomonosov sought to simplify the language of newspapers and magazines and to make it clearer and accessible for the reader. As an interpreter and an editor Lomonosov tried to avoid the difficulties for understanding syntactic constructions, numerous terms and foreign words in academic publications. Lomonosov's traditions in Russia were continued and multiplied in the XVIII century by his disciples and followers: N.N. Popovsky, D.S. Anichkov, S.E. Desnitsky, Y.P. Kozelsky, and other enlighteners. N.N. Popovsky first began to give lectures on philosophy not in Latin, but in Russian language, emphasizing the need of Russian people for free and wide access to the scientific knowledge.

Thus, in the XVIII century in Russia the foundations of ideas about the dissemination of scientific knowledge were laid. This situation has predetermined the formation of the press system, the development of science, education and scientific popularization.

The promoting of scientific knowledge in Russia was carried out in different forms: through public lectures, printed editions of the Academy of Sciences, Moscow University, the Free Economic Society and other educational institutions and public organizations. The popular science journalism was developing in parallel with the existence of other types of literature: scientific, educational and reference. In the first half of the XVIII century specialized scientific and popular science journals have appeared. The genres of popular science publications were formed, the basic principles of selection and presentation of material were determined and the popular science style was developed. The distinctive features of the first popular science publications were encyclopedism and the breadth of the scientific problems of its time, which were the basic characteristics of the multifaceted activities by M.V. Lomonosov.

\section{REFERENCES}

BILYARSKIY, P.S. (1865). Materials for biography of Lomonosov. St Petersburg: Imperial Academy of Sciences (In Russian).

CHRONICLE of life and creativity of M.V. Lomonosov (1961). Moscow; Leningrad: USSR Academy of Sciences (in Russian).

EZHEMESYACHNIE sochineniya I izvestiya ob ychenih delah. 1764. February (in Russian).

GROMOVA, L.P, MAEVSKAYA, M.I. (2012). Popular science journalism in Russia XVIII-XIX centuries: milestones of formation. St Petersburg: St Petersburg State University (in Russian).

GROMOVA, L.P., BALASHOVA, Y.B. (Ed.) (2017). The history of the popular scientific press in Russia in the socio-cultural context. St Petersburg: St Petersburg State University (In Russian).

IN THE TEMPLE of Memory. Literary and critical works about Mikhail Lomonosov. 1765-1865

/ Introduction and commentaries by T. Pirozhkova (2011). Moscow: Moscow State University (in Russian). 
KULYABKO, E.S. (1962). M.V. Lomonosov and the educational activity of the St Petersburg Academy of Sciences. Moscow; Leningrad USSR Academy of Sciences (in Russian).

LOMONOSOV, M. V. (1970). Mikhail Vasil'evich Lomonosov on the corpuscular theory. H. M. Leicester, trans. Cambridge: Harvard University Press.

LOMONOSOV, M.V. (1950). Selected philosophical works. Moscow: Gospolitizdat (in Russian).

MAROV, M. (2005). In transits of Venus: New views of the Solar System and Galaxy. New York: Cambridge University Press.

MENSHUTKIN, B.N. (1911). M.V. Lomonosov. Moscow: Imperial Academy of Sciences (in Russian).

MENSHUTKIN, B.N. (1952). Russia's Lomonosov: Chemist, courtier, physicist, poet. J. E. Thai, E. J. Webster, trans. Princeton: Princeton University Press.

MINAEVA, O.D. (2011). "Fatherland multiply glory...". Biography of M.V. Lomonosov. Moscow: Moscow State University (in Russian).

MOSKVITYANIN. 1849. № 1. Book 1. Dep. III (in Russian).

POLEZNOE uveselenie. 1760. January (in Russian).

TYULICHEV, D.V. (1988). Book publishing activity of the Petersburg Academy of Sciences and M.V. Lomonosov. Leningrad: Nauka (In Russian).

VAVILOV, S.I. (1961). Mikhail Vasilyevich Lomonosov. Moscow: USSR Academy of Sciences (in Russian).

ZAPADOV, A.V. (1961). M.V. Lomonosov and journalism. Moscow: Moscow State University (in Russian). 